\title{
Uji Kesesuaian Pesawat Fluoroskopi Intervensional merek Philips Allura FC menggunakan Detektor Unfors Raysafe X2 di Rumah Sakit Universitas Andalas
}

\author{
Rika Susanti $^{1, *}$, Dian Milvita ${ }^{1}$, Kri Yudi Pati Sandy ${ }^{2}$ \\ ${ }^{1}$ Jurusan Fisika FMIPA Universitas Andalas \\ Kampus Unand, Limau Manis, Padang, 25163 \\ ${ }^{2}$ PTKMR BATAN Jakarta \\ *69rikasusanti@gmail.com
}

\begin{abstract}
ABSTRAK
Telah dilakukan uji kesesuaian pesawat fluoroskopi intervensional merek Philips Allura FC menggunakan detektor unfors raysafe $x 2$ di instalasi radiologi rumah sakit Universitas Andalas. Jenis pengujian yang dilakukan diantaranya uji kualitas citra, uji kolimasi, uji akurasi tegangan, uji kualitas berkas sinar-X, uji laju dosis tipikal pasien, uji kebocoran tabung sinar-X dan uji laju dosis input image intensifier. Hasil yang didapatkan yaitu untuk uji kualitas citra $\geq 1,6 \mathrm{lp} / \mathrm{mm}$; uji kolimasi : (1) uji kesesuaian selisih lapangan kolimasi dengan berkas sinar-X sebesar 0,077\% dan 0,25\%, (2) uji kesesuaian lapangan berkas sinar-X dengan image intensifier sebesar 0,797\% dan 0,503\%, (3) uji kesesuaian titik pusat image intensifier dengan monitor sebesar 0,173\%; uji akurasi tegangan dengan \% error sebesar 4,02\%; uji kualitas berkas sinar-X sebesar 5,14 mmAl pada tegangan $80 \mathrm{kVp}$; uji dosis tipikal pasien sebesar 6,81 mGy/menit dan 11,87 mGy/menit; uji kebocoran tabung sinar-X sebesar 0,159 $\mathrm{mG} / \mathrm{jam}$ dan uji laju dosis input image intensifier sebesar $69,54 \mu \mathrm{Gy} / \mathrm{menit}$ dan $45,84 \mu \mathrm{Gy} / \mathrm{menit}$. Hasil uji dibandingkan dengan nilai lolos uji yang ditetapkan oleh Peraturan Kepala BAPETEN Nomor 9 Tahun 2011. Hasil yang diperoleh yaitu pesawat fluoroskopi intervensional merek Philips Allura FC dalam kondisi andal.

Kata kunci : Uji Kesesuaian, Fluoroskopi Intervensional, Unfors Raysafe X2
\end{abstract}

ABSTRACT

The compliance test on the Philips Allura FC interventional fluoroscopy by using unfors raysafe X2 at Radiology Unit Andalas University Hospital has been conducted. The testing type performed inclued image quality test, collimation test, voltage accuracy test, X-ray beam quality test, typical dose rate of patients test, $X$-ray tube leakage test and rate of dose input image intensifier test. The obtained results for image quality test were $\geq 1.6 \mathrm{lp} / \mathrm{mm}$; collimation test: (1) test of suitability of collimation field difference with X-ray beam was $0.077 \%$ and $0.25 \%$; (2) field suitability test of X-ray beam with image intensifier was $0.797 \%$ and $0.503 \%$; (3) conformity test center point image intensifier with monitor of was $0.173 \%$; Test voltage accuracy with \% error of were $4.02 \%$; An X-ray beam quality test of were 5.14 $\mathrm{mmAl}$ at a voltage of $80 \mathrm{kVp}$; The typical dose of the patient was $6.81 \mathrm{mGy} / \mathrm{min}$ and $11.87 \mathrm{mGy} / \mathrm{min}$; Test of $X$-ray tube leakage of were $0.159 \mathrm{mGy} / \mathrm{hr}$ and rate of dose input image intensifier test rate of was $69.54 \mu \mathrm{Gy} / \mathrm{min}$ and $45.84 \mu \mathrm{Gy} / \mathrm{min}$. Each test result then compare to standard value of the BAPETEN regulation Number 9 of 2011. The result show that interventional fluoroscopy Philips Allura FC is in good condition.

Keywords : Compliance Test, Interventional Fluoroscopy, Unfors Raysafe X2

\section{PENDAHULUAN}

Fluoroskopi intervensional adalah pesawat sinar-X yang memiliki tabir atau lembar penguat fluorosensi yang dilengkapi dengan sistem video yang dapat mencitrakan objek secara langsung (real-time). Fluoroskopi intervensional memiliki tingkat bahaya radiasi yang relatif lebih tinggi daripada pesawat sinar-X lainnya. Hal ini disebabkan karena sinar-X yang dipancarkan secara terus-menerus mengikuti kebutuhan pencitraan yang diinginkan. Oleh sebab itu untuk memastikan fluoroskopi intervensional dalam kondisi andal sebelum dioperasikan, maka harus dilakukan uji kesesuaian (Peraturan Kepala BAPETEN Nomor 9, 2011).

Uji kesesuaian adalah uji untuk memastikan bahwa pesawat tersebut memenuhi persyaratan keselamatan radiasi dan memberikan informasi diagnosik yang tepat dan akurat. Pengukuran pada uji kesesuaian diharapkan memberikan estimasi terbaik terhadap parameter uji kesesuaian. Hasil pengujian harus memenuhi suatu nilai standar atau batas toleransi tertentu agar menjadi pedoman bagi pemilik fasilitas untuk mengambil tindakan yang terbaik seperti perbaikan peralatan atau mengganti dengan pesawat yang baru. Uji kesesuaian menggunakan 232 
alat ukur khusus, yang dilakukan oleh tenaga fisikawan medis yang telah terdidik dalam aspek administrasi, teknis, dan kinerja klinis pada peralatan pesawat sinar-X yang mampu menilai kinerja peralatan dari pesawat sinar-X. Uji kesesuaian pesawat sinar-X untuk radiologi diagnostik dan intervensional diatur dalam Peraturan Kepala BAPETEN Nomor 9 tahun 2011.

Dhara (2013) telah melakukan penelitian terhadap parameter uji kolimasi, uji generator dan tabung sinar-X, uji dosimetri dan uji kualitas citra pada tiga pesawat fluoroskopi intervensional dengan spesifikasi berbeda di Rumah Sakit Universitas Hasanuddin Makasar. Hasil penelitian menunjukkan bahwa pengujian ketiga pesawat memiliki kualitas yang cukup baik, ditinjau dari generator dan tabung sinar-X, dosimetri dan kualitas citra.

Latif (2016) telah melakukan penelitian terhadap parameter laju dosis pesawat fluoroskopi intervensional menggunakan multimeter sinar-X di Rumah Sakit Universitas Hasanuddin Makasar. Hasil penelitian menunjukkan bahwa hasil pengukuran Entrace Surface Dose (ESD) tipikal yang diperoleh nilai rata-rata sebesar 18,759 Gy/menit, hasil ini tidak sesuai dengan standar lolos uji yang ditetapkan oleh BAPETEN yaitu $\leq 15 \mathrm{~Gy} / \mathrm{menit}$, sedangkan untuk laju dosis dipermukaan image intensifier diperoleh nilai rata-rata sebesar 23,252 Gy/menit, hasil ini sesuai dengan standar lolos uji yang dikeluarkan oleh BAPETEN yaitu $\leq 80 \quad \mathrm{~Gy} /$ menit.

Dewi (2016) telah melakukan penelitian terhadap parameter kolimasi berkas sinar-X di Rumah Sakit Universitas Hasanuddin Makasar. Pada pengukuran kesesuaian titik pusat image intensifier dan monitor rata-rata ukuran yang diperoleh yaitu $10,4 \mathrm{~cm}$ dan $10,3 \mathrm{~cm}$, sedangkan pada area berkas sinar-X dengan monitor dan pada pengukuran kesesuaian area berkas sinar-X dengan image intensifier rata-rata ukuran area berkas sinar-X yang diperoleh sama yaitu 20,7 $\mathrm{cm}$. Hasil penelitian menunjukkan bahwa pesawat fluoroskopi intervensional di Rumah Sakit Universitas Hasanuddin masih memenuhi batas nilai lolos uji yaitu lebih kecil atau sama dengan nilai lolos uji yang telah ditetapkan.

Pada penelitian ini dilakukan uji kesesuaian terhadap pesawat fluoroskopi intervensional merek Philips Allura FC di Instalasi Radiologi Rumah Sakit Universitas Andalas. Sesuai Peraturan Pemerintah Republik Indonesia Nomor 33 Tahun 2007 tentang keselamatan radiasi pengion dan keamanan sumber radioaktif bahwa setiap rumah sakit yang memiliki jasa medis yang memanfaatkan sumber radioaktif harus menjamin keamanan alat medis yang digunakan dengan melakukan uji kesesuaian alat medis demi keselamatan banyak orang. Uji kesesuaian sangat penting dilakukan, selain mematuhi peraturan yang telah diatur pemerintah, juga untuk meningkatkan pelayanan dan mutu rumah sakit. Peralatan medis yang memenuhi standar keamanan akan lebih dipercaya untuk digunakan oleh masyarakat, terutama masyarakat ilmiah yang semakin kritis terhadap jasa medis.

\section{METODE}

Alat yang digunakan pada penelitian ini adalah pesawat fluoroskopi intervensional merek Philips Allura FC sebagai objek uji kesesuaian, detektor unfors raysafe $x 2$ yang terdiri dari : (1) x2 R/F Detector Platinum untuk mengukur akurasi tegangan, waktu, laju dosis dan half value layer; (2) $x 2$ survey platinum untuk mengukur laju kebocoran tabung sinar-X dan (3) $x 2$ base unit platinum untuk menampilkan nilai yang terukur pada detektor. Fantom digunakan sebagai pengganti pasien.

\subsection{Uji Kualitas Citra}

Uji kualitas citra dilakukan melalui tahapan sebagai berikut : (1) Alat dipersiapkan lalu fantom ditempelkan ke image intensifier menggunakan selotip, (2) Penyinaran dilakukan dan hasil citra disimpan pada komputer, (3) Hasil citra diolah menggunakan software imageJ dan (4) Data yang didapatkan lalu dibandingkan dengan nilai lolos uji yang dikeluarkan oleh BAPETEN

\subsection{Uji Kolimasi}

Uji kolimasi dilakukan melalui tahapan sebagai berikut : (1) alat dipersiapkan lalu image receptor dan beam aligment test tool ditempelkan ke image intensifier menggunakan 
selotif, (2) penyinaran dilakukan dan hasil citra disimpan pada komputer, (3) hasil citra diolah menggunakan software imageJ, (4) data yang didapatkan dari software imageJ dihitung menggunakan Persamaan

$$
\begin{gathered}
\text { Faktor Jarak }=\text { SID/SOD } \\
\text { AEM terkoreksi }(\mathrm{cm})=\text { AEM terukur } \times \text { Faktor jarak } \\
\text { Deviasi }(\% \text { SID })=(\text { ukuran II }- \text { AEM terkoreksi }) /(\text { ukuran II }) \times 100 \% \\
\text { ASX terkoreksi }(\mathrm{cm})=\text { ASX terukur } \times \text { Faktor jarak } \\
\text { Selisih ASX terukur dengan II }=\text { ASX terukur }- \text { ukuran II } \\
\text { Deviasi }(\% \text { SID })=(\text { Selisih ASX terukur dengan II }) / \text { SID } \times 100 \% \\
\text { Deviasi }(\% \text { SID })=(\text { Jarak titik pusat II ke monitor }) / \text { SID } \times 100 \%
\end{gathered}
$$

II adalah image intersifier, SID adalah jarak fokal spot ke II, SOD adalah jarak fokal spot ke objek, $A E M$ adalah area efektif monitor dan $A S X$ adalah area sinar-X.

\subsection{Uji Akurasi Tegangan}

Uji kualitas akurasi tegangan dilakukan melalui tahapan sebagai berikut : (1) alat dipersiapkan lalu $x 2 R / F$ detector platinum ditempelkan ke image intensifier dan lempeng tembaga ditempelkan secara bergantian dengan ketebalan (1-7) $\mathrm{mm}$ ke $x 2 \mathrm{R} / \mathrm{F}$ detector platinum menggunakan selotip, (2) Penyinaran dilakukan secara bergantian Data yang ditampilkan pada base unit platinum dicatat, (3) diolah menggunakan Persamaan (8) dan (4) data yang didapatkan dari Persamaan (8) lalu dibandingkan dengan nilai lolos uji yang dikeluarkan oleh BAPETEN.

$$
\text { error } \left.(\%)=\mid<\mathrm{kV} \_(\text {p_((set) })\right)-\mathrm{kV} \_(\text {p_((ukur) })>/ \mathrm{kV} \_\left(\mathrm{p} \_((\text {set }))\right) \mid \times 100 \%
$$

$k V p_{(s e t)}$ adalah tegangan pada panel kendali, $k V p_{(u k u r)}$ adalah tegangan yang terukur pada detektor dan $e$ adalah persentasi error (\%).

\subsection{Uji Kualitas Berkas Sinar-X (Half Value Layer)}

Uji kualitas berkas sinar-X (Half Value Layer) dilakukan melalui tahapan sebagai berikut : (1) alat dipersiapkan lalu $x 2 R / F$ detector platinum ditempelkan ke image intensifier dan lempeng tembaga ditempelkan secara bergantian dengan ketebalan (1-6) mm ke $x 2 R / F$ detector platinum menggunakan selotif, (2) penyinaran dilakukan secara bergantian, (3) data yang ditampilkan pada base unit platinum dicatat dan (4) data yang dicatat lalu dibandingkan dengan nilai lolos uji yang dikeluarkan oleh BAPETEN.

\subsection{Uji Laju Dosis Tipikal Pasien}

Uji laju dosis tipikal pasien dilakukan melalui tahapan sebagai berikut : (1) alat dipersiapkan lalu $x 2 R / F$ detector platinum diletakkan pada tiang penyangga dan lempeng tembaga ditempelkan secara bergantian dengan ketebalan $2 \mathrm{~mm}$ dan $3 \mathrm{~mm}$ ke image intensifier menggunakan selotip, (2) penyinaran dilakukan secara bergantian, (3) data yang ditampilkan pada base unit platinum dicatat dan (4) data yang dicatat lalu dibandingkan dengan nilai lolos uji yang dikeluarkan oleh BAPETEN.

\subsection{Uji Kebocoran Tabung Sinar-X}

Uji laju dosis tipikal pasien dilakukan melalui tahapan sebagai berikut : (1) alat dipersiapkan lalu survey platinum diletakkan pada titik A(depan), B (belakang), C (kanan),D ( kiri) dan $\mathrm{E}$ (bawah) tabung sinar-X secara bergantian dengan jarak $100 \mathrm{~cm}$ dari tabung tempat keluarnya sinar-X, (2) Penyinaran dilakukan secara bergantian, (3) data yang ditampilkan pada base unit platinum dicatat dan diolah menggunakan Persamaan (9) dan (4) data yang didapatkan dari Persamaan (9) lalu dibandingkan dengan nilai lolos uji yang dikeluarkan oleh BAPETEN.

$$
\mathrm{L}=\mathrm{X}\left(\left(\mathrm{kV} \_\left(\mathrm{p} \_(\max )\right)\right) /\left(\mathrm{kV} \_\left(\mathrm{p} \_((\mathrm{set}))\right)\right)\left(\left(\mathrm{mA} \_(\mathrm{cont}) / \mathrm{mA} \_(\text {set })\right)\right) \quad(1 / 1000)\right.
$$


$L$ adalah laju kebocoran tabung sinar-X, $X$ adalah laju dosis terukur, $k V p(s e t)$ adalah tegangan pada saat penyinaran dilakukan, $k V p(\max )$ adalah tegangan maksimum pada panel kendali, $m A($ set $)$ adalah arus pada saat penyinaran dilakukan, dan $m A$ (cont) adalah arus kontinu pada panel kendali.

\subsection{Uji Laju Input Image Intensifier}

Uji laju input image intensifier dilakukan melalui tahapan sebagai berikut : (1) alat dipersiapkan lalu $x 2 R / F$ detector platinum diletakkan pada tiang penyangga dan lempeng tembaga ditempelkan secara bergantian dengan ketebalan $2 \mathrm{~mm}$ dan $3 \mathrm{~mm}$ ke image intensifier menggunakan selotip, (2) penyinaran dilakukan secara bergantian, (3) data yang ditampilkan pada base unit platinum dicatat, dan (4) data yang dicatat lalu dibandingkan dengan nilai lolos uji yang dikeluarkan oleh BAPETEN.

\section{HASIL DAN DISKUSI}

\subsection{Uji Kualitas Citra}

Berdasarkan penelitian uji kualitas citra pada pesawat fluoroskopi intervensional merek Philips Allura FC diperoleh data yang dapat dilihat pada Tabel 1. Tabel 1 menunjukkan terdapat 21 data resolusi spasial, tetapi hanya ada 2 data yang lolos nilai uji yang diperkenankan oleh BAPETEN. Batas toleransi gambaran yang menunjukkan perbedaan antara nilai keabuan dengan jaraknya dapat dilihat pada gambar nomor 11 dan gambar nomor 12 yang ditampilkan secara visual pada Gambar 1 dan secara software ImageJ pada Gambar 2 (a) dan Gambar 2 (b).

Tabel 1 Data Hasi Uji Resolusi Spasial

\begin{tabular}{|c|c|c|c|}
\hline No & Visual (lp/mm) & ImageJ (lp/mm) & Nilai Lolos uji \\
\hline 1 & 0,50 & 0,50 & \\
\hline 2 & 0,56 & 0,56 & \\
\hline 3 & 0,63 & 0,63 & \\
\hline 4 & 0,71 & 0,71 & \\
\hline 5 & 0,80 & 0,80 & \\
\hline 6 & 0,90 & 0,90 & \\
\hline 7 & 1,00 & 1,00 & \\
\hline 8 & 1,12 & 1,12 & \\
\hline 9 & 1,25 & 1,25 & \\
\hline 10 & 1,40 & 1,40 & \\
\hline 11 & 1,60 & 1,60 & \\
\hline 12 & 1,80 & 1,80 & $\geq 1,6 \mathrm{lp} / \mathrm{mm}$ \\
\hline 13 & 2,00 & 2,00 & \\
\hline 14 & 2,24 & 2,24 & \\
\hline 15 & 2,50 & 2,50 & \\
\hline 16 & 2,80 & 2,80 & \\
\hline 17 & 3,15 & 3,15 & \\
\hline 18 & 3,55 & 3,55 & \\
\hline 19 & 4,00 & 4,00 & \\
\hline 20 & 4,50 & 4,50 & \\
\hline 21 & 5,00 & 5,00 & \\
\hline
\end{tabular}




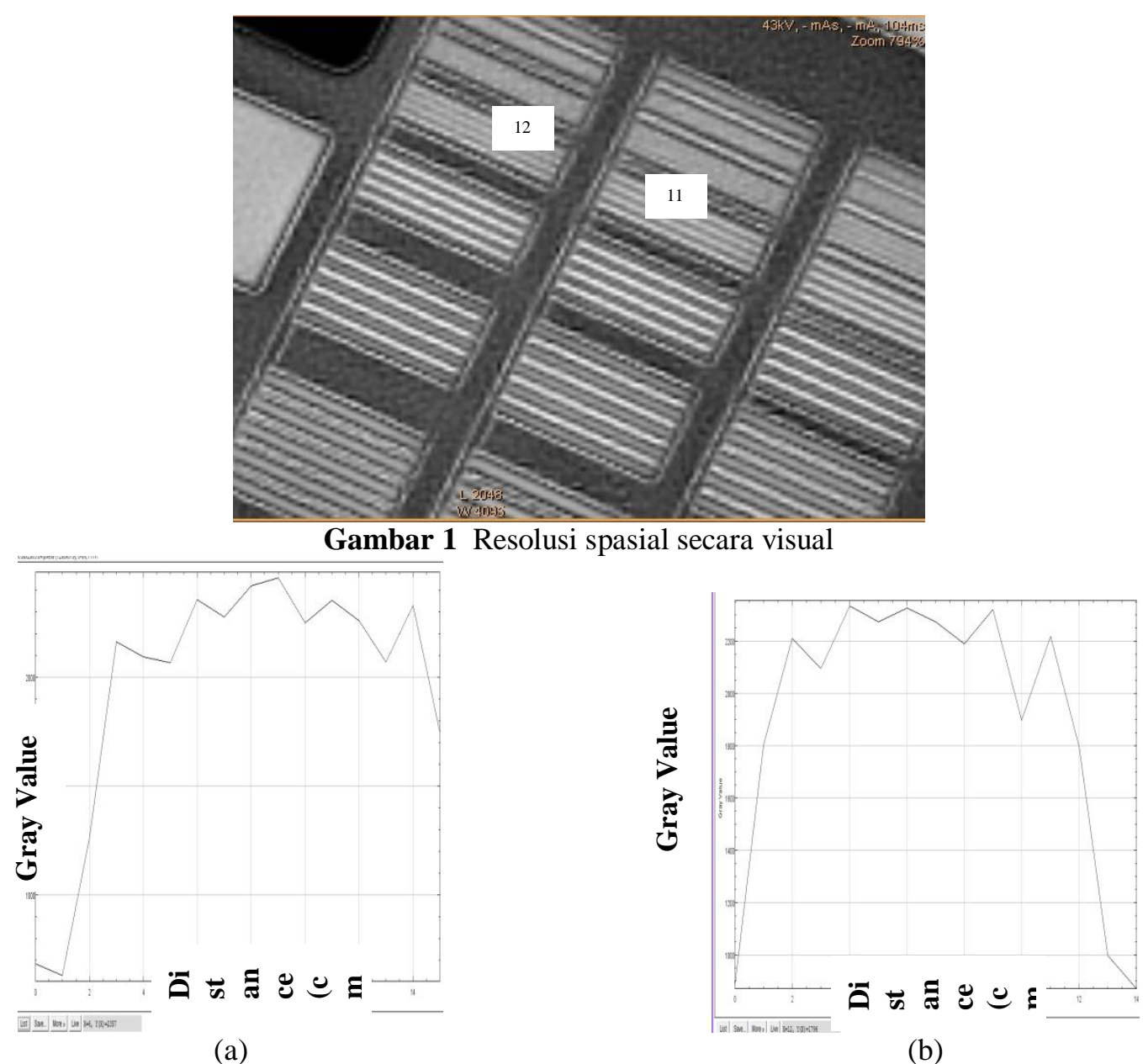

(a)

(b)

Gambar 2 Resolusi Spasial secara software ImageJ (a) nomor 11 dan (b) nomor 12

Berdasarkan Gambar 1, Gambar 2 (a) dan Gambar 2 (b) batas ambang kontras terlihat pada gambar nomor 11 dan gambar nomor 12 dengan nilai resolusi spasial 1,60 lp/mm dan 1,80 lp/mm. Pada Gambar 2 (a) dan Gambar 2 (b) batas ambang kontras ditunjukkan dengan masih terlihatnya lima puncak yang bagus pada grafik.

\subsection{Uji Kolimasi}

Berdasarkan penelitian uji kolimasi dilakukan 3 sub uji diantaranya yaitu : (1) uji kesesuaian selisih lapangan kolimasi dengan berkas sinar-X, (2) uji kesesuaian lapangan berkas sinar-X dengan image intensifier dan (3) uji kesesuaian titik pusat image intensifier dengan monitor pada pesawat fluoroskopi intervensional merek Philips Allura FC.

\subsubsection{Uji Kesesuaian Selisih Lapangan Kolimasi dengan Berkas Sinar-X}

Berdasarkan penelitian uji kesesuaian selisih lapangan kolimasi dengan berkas sinar-X pada pesawat fluoroskopi intervensional merek Philips Allura FC diperoleh data yang dapat dilihat pada Tabel 2. Tabel 2 menunjukkan nilai \% SID horizontal dan \% SID vertikal yang diujikan pada pesawat fluoroskopi intervensional masih di bawah nilai lolos uji yang diperkenankan BAPETEN, yaitu $\%$ SID $\leq 10 \%$. Tabel 2 juga menunjukkan bahwa semakin besar nilai AEM terkoreksi maka semakin besar \% SID yang dihasilkan, sedangkan semakin kecil nilai AEM terkoreksi maka semakin kecil pula \% SID yang dihasilkan.

Tabel 2 Data Hasil Uji Kesesuaian Selisih Lapangan Kolimasi dengan Berkas Sinar-X

\begin{tabular}{ccccc}
\hline $\begin{array}{c}\text { AEM vertikal } \\
\text { terkoreksi }(\mathbf{c m})\end{array}$ & $\begin{array}{c}\text { AEM horizontal } \\
\text { terkoreksi }(\mathbf{c m})\end{array}$ & $\begin{array}{c}\text { \%SID } \\
\text { vertikal }\end{array}$ & $\begin{array}{c}\text { \% SID } \\
\text { horizontal }\end{array}$ & $\begin{array}{c}\text { Nilai } \\
\text { Lolos Uji }\end{array}$ \\
\hline 21,99 & 22,03 & $0,077 \%$ & $0,35 \%$ & $10 \%$ \\
\hline
\end{tabular}




\subsubsection{Uji Kesesuaian Lapangan Berkas Sinar-X dengan Image Intensifier}

Berdasarkan penelitian uji kolimasi kesesuaian lapangan berkas dengan image intensifier pada pesawat fluoroskopi intervensional merek Philips Allura FC diperoleh data yang dapat dilihat pada Tabel 3. Tabel 3 menunjukkan nilai \% SID horizontal dan \% SID vertikal antara kesesuaian lapangan berkas dengan image intensifier yang diujikan pada pesawat fluoroskopi intervensional masih di bawah nilai lolos uji yang diperkenankan oleh BAPETEN, yaitu \% SID $\leq 1 \%$. Tabel 3 juga menunjukkan bahwa semakin besar nilai ASX terkoreksi maka semakin besar \% SID yang dihasilkan, sedangkan semakin kecil nilai ASX terkoreksi maka semakin kecil pula \% SID yang dihasilkan dan menunjukkan bahwa ukuran lapangan berkas sinar-X dengan image intensifier mendekati sama besar, sehingga radiasi yang dikeluarkan akan diterima image intensifier sesuai dengan berkas sinar-X yang dipancarkan.

Tabel 3 Data Hasil Uji Kesesuaian Lapangan Berkas Sinar-X dengan Image Intensifier

\begin{tabular}{ccccc}
\hline $\begin{array}{c}\text { ASX vertikal } \\
\text { terkoreksi }(\mathrm{cm})\end{array}$ & $\begin{array}{c}\text { ASX horizontal } \\
\text { terkoreksi }(\mathrm{cm})\end{array}$ & $\begin{array}{c}\text { \% SID } \\
\text { vertikal }\end{array}$ & $\begin{array}{c}\text { \% SID } \\
\text { horizontal }\end{array}$ & $\begin{array}{c}\text { Nilai } \\
\text { Lolos Uji }\end{array}$ \\
\hline 22,83 & 23 & $0,503 \%$ & $0,797 \%$ & $1 \%$ \\
\hline
\end{tabular}

\subsubsection{Uji Kesesuaian Titik Pusat Image Intensifier dengan Monitor}

Berdasarkan penelitian uji kesesuaian titik pusat image intensifier dengan monitor pada pesawat fluoroskopi intervensional merek Philips Allura FC diperoleh data yang dapat dilihat pada Tabel 4. Tabel 4 menunjukkan nilai \% SID untuk uji kesesuaian titik pusat image intensifier dengan monitor yang diujikan pada pesawat fluoroskopi intervensional masih di bawah nilai lolos uji yang diperkenankan oleh BAPETEN, yaitu $\%$ SID $\leq 1 \%$. Tabel 4 menunjukkan bahwa semakin kecil \% SID maka jarak fokus akan semakin dekat dan sebaliknya semakin besar \% SID maka jarak fokus akan semakin jauh.

Tabel 4 Data Hasil Uji Kesesuaian Titik Pusat Image Intensifier dengan Monitor

\begin{tabular}{ccccc}
\hline $\begin{array}{c}\text { Ukuran image } \\
\text { intensifier }(\mathbf{c m})\end{array}$ & SID (cm) & $\begin{array}{c}\text { Jarak image intensifier } \\
\text { ke monitor }(\mathbf{c m})\end{array}$ & \% SID & $\begin{array}{c}\text { Nilai } \\
\text { Lolos Uji }\end{array}$ \\
\hline 22 & 120 & 0,207 & $0,173 \%$ & $1 \%$ \\
\hline
\end{tabular}

\subsubsection{Uji Akurasi Tegangan}

Berdasarkan penelitian uji akurasi tegangan pesawat fluoroskopi intervensional merek Philips Allura FC diperoleh data yang dapat dilihat pada Tabel 5. Pada Tabel 5 menunjukkan bahwa nilai rata-rata akurasi tegangan yang diujikan pada pesawat fluoroskopi intervensional masih di bawah nilai lolos uji yang diperkenankan oleh BAPETEN, yaitu $e_{\text {maks }} \leq 10 \%$. Artinya, nilai tegangan yang terukur masih mendekati tegangan yang diatur pada panel kontrol. Pada kenyataannya keadaan ideal sangat sulit dicapai karena ketika pesawat fluoroskopi intervensional melakukan proses penyinaran, akan terjadi pengurangan efisiensi kerja. Faktorfaktor yang mempengaruhi efisiensi kerja pesawat yaitu pemakaian pesawat secara berulangulang, kestabilan tergangan listrik yang digunakan serta pemindahan alat dari satu lokasi ke lokasi lainnya.

Tabel 5 Data Hasil Uji Akurasi Tegangan

\begin{tabular}{ccccc}
\hline No & $\mathbf{k V p _ { \text { panel } }}$ & $\mathbf{k V p _ { \text { terukur } }}$ & \% error & Nilai Lolos Uji \\
\hline 1 & 59 & 58,9 & $0,17 \%$ & \\
2 & 67 & 65,5 & $2,24 \%$ & \\
3 & 73 & 70,8 & $4,02 \%$ & $10 \%$ \\
4 & 79 & 77,1 & $2,40 \%$ & \\
5 & 86 & 85,1 & $1,05 \%$ & \\
6 & 91 & 91 & $0 \%$ & \\
7 & 97 & 96,7 & $0,31 \%$ & \\
8 & 125 & 126,7 & $1,37 \%$ & \\
\hline
\end{tabular}




\subsubsection{Uji Kualitas Berkas Sinar-X (Half Value Layer)}

Berdasarkan penelitian uji kualitas berkas sinar-X (Half Value Layer) pesawat fluoroskopi intervensional merek Philips Allura FC diperoleh data yang dapat dilihat pada Tabel 6. Tabel 6 menunjukkan nilai rata-rata HVL yang diujikan pada pesawat fluoroskopi intervensional masih di bawah nilai lolos uji yang diperkenankan oleh BAPETEN, yaitu HVL adalah $\geq 2,3 \mathrm{mmAl}$. HVL menyatakan kemampuan filtrasi pesawat fluoroskopi intervensional untuk menyaring dosis radiasi yang dipaparkan sinar-X. Tabel 6 juga menunjukkan bahwa semakin besar nilai HVL menunjukkan semakin besar daya tembus dan intensitas radiasi, sehingga kualitas berkas radiasi yang dihasilkan semakin baik. Kualitas berkas sinar-X sangat perlu diketahui agar tujuan diagnostik tercapai, yaitu citra dapat dianalisis dengan baik dan tepat oleh dokter serta meminimalisasi dosis radiasi yang diterima pasien.

Tabel 6 Data Hasil Uji Kualitas Berkas Sinar-X (Half Value Layer)

\begin{tabular}{cccc}
\hline No & Filter $(\mathbf{m m})$ & HVL $(\mathbf{m m A l})$ & Nilai Lolos Uji (mmAl) \\
\hline 1 & 1 & 3,88 & \\
2 & 2 & 4,42 & 2,3 \\
3 & 3 & 4,82 & \\
4 & 4 & 5,14 & \\
5 & 5 & 5,60 & \\
6 & 6 & 5,91 & \\
\hline
\end{tabular}

\subsubsection{Uji Laju Dosis Tipikal Pasien}

Berdasarkan penelitian uji laju dosis tipikal pasien pada pesawat fluoroskopi intervensional Philips Allura FC diperoleh data Tabel 7. Tabel 7 menunjukkan nilai laju dosis pasien tipikal yang diujikan pada pesawat fluoroskopi intervensional masih di bawah nilai lolos uji yang diperkenankan oleh BAPETEN, yaitu laju dosis adalah $\leq 15 \mathrm{mGy} / \mathrm{menit}$. Tabel 7 menunjukkan juga bahwa semakin besar nilai tegangan $(\mathrm{kVp})$ dan arus $(\mathrm{mA})$ maka semakin besar juga nilai laju dosis yang diterima pasien, sedangkan semakin kecil nilai tegangan $(\mathrm{kVp})$ dan arus (mA) maka semakin kecil nilai laju dosis yang diterima pasien.

Tabel 7 Data Hasil Uji Dosis Tipikal Pasien

\begin{tabular}{cccc}
\hline No & Tembaga ( mm ) & Laju Dosis (mGy/menit) & Nilai lolos uji (mGy/menit) \\
\hline 1 & 2 & 6,81 & 15 \\
2 & 3 & 11,87 & 15
\end{tabular}

\subsubsection{Uji Kebocoran Tabung Sinar-X}

Berdasarkan penelitian uji kebocoran tabung sinar-X pesawat fluoroskopi intervensional merek Philips Allura FC diperoleh data yang dapat dilihat pada Tabel 8. Tabel 8 menunjukkan nilai laju kebocoran tabung sinar-X yang diujikan pada pesawat fluoroskopi intervensional masih di bawah nilai lolos uji yang diperkenankan oleh BAPETEN, yaitu laju dosis adalah $\mathrm{L}_{\text {maks }} \leq 1 \mathrm{mGy} / \mathrm{jam}$. Laju kebocoran tabung sinar-X yang dihasilkan tidak boleh melebihi $1 \mathrm{mGy} / \mathrm{jam}$. Jika laju kebocoran tabung sinar-X yang dihasilkan melebihi batas yang diberikan, maka perlu dilakukan suatu perlindungan terhadap tabung sinar-X dengan memberikan perlindung tambahan di sekitar tabung sinar-X.

Tabel 8 Data Hasil Uji Kebocoran Tabung Sinar-X

\begin{tabular}{ccccc}
\hline No & $\mathbf{X}(\boldsymbol{\mu G} \mathbf{G} / \mathbf{j a m})$ & Posisi & $\begin{array}{c}\text { Laju Kebocoran } \\
(\mathbf{m G y} / \mathbf{j a m})\end{array}$ & $\begin{array}{c}\text { Nilai Lolos Uji } \\
(\mathbf{m G y} / \mathbf{J a m})\end{array}$ \\
\hline 1 & 318,9 & Kiri & 0,159 & \\
2 & 155 & Belakang & 0,078 & 1 \\
3 & 190,2 & Depan & 0,095 & \\
4 & 301,4 & Kanan & 0,151 & \\
5 & 33,2 & Bawah & 0,002 & \\
\hline
\end{tabular}




\subsubsection{Uji Laju Dosis Input Image Intensifier}

Berdasarkan penelitian uji laju dosis input image intensifier pesawat fluoroskopi intervensional merek Philips Allura FC diperoleh data yang dapat dilihat pada Tabel 9. Tabel 9 menunjukkan nilai laju dosis input image intensifier yang diujikan pada pesawat fluoroskopi intervensional masih di bawah nilai lolos uji yang diperkenankan oleh BAPETEN, yaitu nilai laju dosis untuk diameter $11 \mathrm{~cm} \leq 120 \mu \mathrm{Gy} /$ menit dan untuk diameter $17 \mathrm{~cm} \leq 80 \mu \mathrm{Gy} /$ menit. Tabel 9 juga menunjukkan bahwa semakin besar ukuran image intensifier maka semakin kecil laju dosis yang dihasilkan, sedangkan semakin kecil ukuran image intensifier maka semakin besar laju dosis yang dihasilkan.

Tabel 9 Data Hasil Uji Dosis Input Image Intensifier

\begin{tabular}{cccccc}
\hline No & $\begin{array}{c}\text { Tembaga } \\
(\mathbf{~ m m})\end{array}$ & $\begin{array}{c}\text { Ukuran image } \\
\text { intensifier }(\mathbf{c m})\end{array}$ & $\begin{array}{c}\text { Laju Dosis } \\
(\boldsymbol{\mu G y / m e n i t )}\end{array}$ & $\begin{array}{c}\text { Laju Dosis Rata- } \\
\text { rata }(\boldsymbol{\mu G y} / \mathbf{m e n i t})\end{array}$ & $\begin{array}{c}\text { Nilai Lolos Uji } \\
(\boldsymbol{\mu G y} / \mathbf{m e n i t})\end{array}$ \\
\hline 1 & 2 & 11 & 69,60 & 69,54 & 120 \\
2 & 3 & 11 & 69,48 & & 80 \\
3 & 2 & 22 & 49,20 & 45,84 & \\
4 & 3 & 22 & 42,48 & & \\
\hline
\end{tabular}

\section{KESIMPULAN}

Kesimpulan dari penelitian ini adalah pesawat fluoroskopi intervensional merek Philips Allura FC di Rumah Sakit Universitas Andalas yang menjadi objek pada penelitian secara umum berada dalam kondisi baik. Hasil yang didapatkan berada di bawah nilai lolos uji yang diperbolehkan oleh Peraturan Kepala BAPETEN Nomor 9 Tahun 2011.

\section{DAFTAR PUSTAKA}

BAPETEN, 2011, Peraturan Kepala Badan Pengawas Tenaga Nuklir Nomor 9 Tentang Uji Kesesuaian Pesawat Sinar-X Radiologi Diagnostik dan Intervensional. Dokumen Teknis, Badan Pengawas Tenaga Nuklir, Jakarta.

Dewi, G.A.D.S, 2016, Analisis Kolimasi Berkas pada Pesawat Fluoroscopy (Mobile C-Arm) di Rumah Sakit Universitas Hasanuddin, Skripsi, FMIPA, UNHAS, Makasar.

Dhara St.R.R., 2013, Uji Kontrol Pesawat Radiologi Intervensional, Skripsi, FMIPA, UNHAS, Makasar.

Latif, A., 2016, Penentuan Laju Dosis pada Pesawat Sinar-X Fluoroscopy (Mobile C-Arm) di Rumah Sakit Universitas Hasanuddin, Skripsi, FMIPA, UNHAS, Makasar. 